\title{
NEGOTIN LOWLAND IRRIGATION SYSTEM UPGRADING ${ }^{1}$
}

\author{
Vesna Popović², Nataša Kljajič́3, Jonel Subičc ${ }^{4}$
}

\begin{abstract}
Summary
According to FAO concept of irrigation modernisation, to be effective, an irrigation system must be based on improved irrigation efficiency, reduced operation and maintenance costs and improved cost recovery based on raised agricultural productivity, with due consideration to the institutional and legal-related issues and environment protection. To make the irrigation system successfully upgraded, the project needs to undergo a comprehensive analysis of the factors that lead to the modernization.

Using the IPTRID/FAO-AGLW methodological approach of addressing causes for irrigation modernization, the authors in the paper review technical, socio-institutional, economic-financial and environmental causes for upgrading of the irrigation system in the Negotin lowland and give some recommendations for successful realization of this project, based on international and regional experiences and adjusted to specificities of local agriculture and rural communities.
\end{abstract}

Key words: irrigation system modernization, irrigated agriculture profitability, water users' associations.

JEL: $Q 15$

\section{Introduction}

Agriculture accounts for $70 \%$ of global water withdrawals (UN, 2011). The estimations indicate that the potential water savings in the EU irrigation sector would amount to $43 \%$ of the current agricultural volume abstracted (Ecologic, 2007).

1 Paper is a part of research within the project no. III 46006 - Sustainable agriculture and rural development in the function of accomplishing strategic objectives of the Republic of Serbia in the Danube region, financed by the Ministry of Education, Science and Technological Development of the Republic of Serbia. Project period: 2011-2014.

2 Vesna Popović, Ph.D., Principal Research Felow, Institute of Agricultural Economics, Volgina Street no. 15, 11060 Belgrade, Serbia, Phone: + 381116972 858, E-mail: vesna p@iep.bg.ac.rs

3 Nataša Kljajić, Ph.D., Research Associate, Institute of Agricultural Economics, Volgina Street no. 15, 11060 Belgrade, Serbia, Phone: + 381116972 858, E-mail: nataša k@,iep.bg.ac.rs

4 Jonel Subić, Ph.D., Senior Research Associate, Institute of Agricultural Economics, Volgina Street no. 15, 11060 Belgrade, Serbia, Phone: + 381116972 858, E-mail: jonel_s@iep.bg.ac.rs

EP 2014 (61) 3 (739-757) 
Water savings can be carried out with improvements in irrigation infrastructure and technologies, including irrigation management transfer and participatory irrigation management to assure that irrigated agriculture become more productive while assuring environment conservation. This "integrated approach of technical and managerial upgrading of irrigation schemes combined with institutional reforms with the objective to improve resource utilization (labour, water economics, and environment) and water delivery service to farms" is defined by FAO as the Concept of Irrigation Modernization ${ }^{5}$ (Wolters, Burt, 1997). Irrigation and drainage will be more site-specific and much more closely linked with policies and plans in agriculture and other sectors (Svendsen, Turral, 2007).

The irrigation sector in Southeastern European countries in transition has undergone dramatic period over the last two decades, characterised by the sharp decline in budget subsidies and poor results in collection of water charges that caused serious delays in maintenance and investment in the irrigation sector. Furthermore, the Fourth Assessment Report of the Intergovernmental Panel on Climate Change (2007) indicates that climate change is projected to worsen in Southern Europe and to reduce water availability, hydropower potential and crop productivity.

The Republic of Serbia has chosen irrigation and maintenance of irrigation systems as the main mitigation practices regarding drought (DMCSEE, 2011).

Irrigation systems have been built mainly on land under classes I and II of suitability for irrigation. Under clases I - III around 3,641,000 ha are grouped, of which around 1,600,000 ha are in the clases I-II of the most productive land for irrigation (IJČ, 2001).

According to 2013 statistics, which monitors irrigation on agricultural land of business entities and cooperatives, 85,593 ha were covered by irrigation systems of which 53,086 ha were irrigated $(62 \%)$. The share of irrigated land in utilized agricultural area was $1 \%$. Total water abstracted for irrigation was 88,130 thous. $\mathrm{m}^{3}$. Most was pumped from rivers (91\%) while the rest was abstracted from the groundwater, lakes, reservoirs and public water supply network (RZS, 2014). Agricultural census (2012) has a broader scope of research and in addition to agricultural land of legal entities and entrepreneurs includes family farms. According to these data, in 2011/2012 production year, 71,947 agricultural holdings (11,4\%) irrigated 99,773 ha. Family farms mostly use groundwater for irrigation, hence it is the main source of water for irrigation $(51.6 \%)$, while surface water outside holding accounted $31 \%$ (RZS, 2013a).

Faced with a lack of funds for the rehabilitation and upgrading of irrigation and drainage systems degraded due to poor maintenance in the years of economic crisis and transition, the Republic of Serbia concluded with the IBRD/IDA Development Credit Agreement (2005) and Additional Financing Loan Agreement (2007) for financing Irrigation \& Drainage Rehabilitation Project in the 2005-2014 period.

Along with the above-mentioned activities, in 2012 the Ministry of Agriculture-Agricultural

5 The irrigation modernization refers to both irrigation and drainage related actions, but the analysis in this paper will focus only on irrigation. 
Land Department is starting with the implementation of a project of rehabilitation, revitalization, reconstruction, modernization and construction of irrigation systems. Among the priorities of the project is the upgrading of hydro-system for the irrigation of the part of Negotin lowland (JVP "Srbijavode", 2014).

The subject of analysis in this paper are the causes for upgrading the Hs Negotin lowland and its profitable exploitation for irrigation in the future. The results should be used as feedback to ongoing and future irrigation modernization process in the region.

\section{Data sources and used methodology}

Research was based on IPTRID/FAO-AGLW methodological approach (2002) of addressing causes for irrigation modernization based on "4-branch tree" areas of concern: (1) technical, (2) socio-institutional, (3) economic-financial and (4) environmental (Figure 1).

Figure 1. Causes for Irrigation Modernization

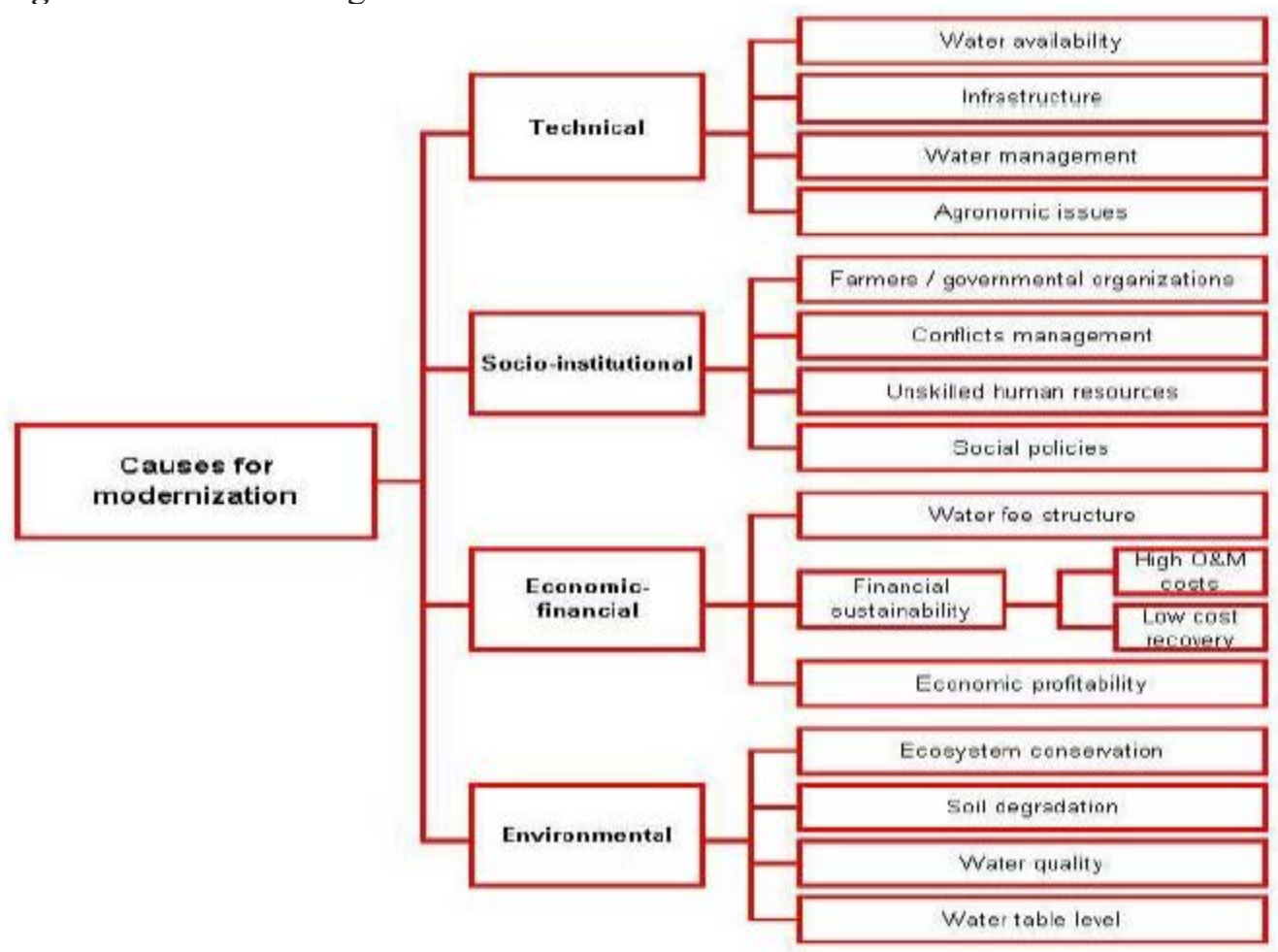

Source: IPTRID/FAO-AGLW Collaborative Initiative, (2002).

According to the methodological guideline, it is not necessarily that all these elements need to be present in every modernisation process. What will be included depend of the sitespecificities and scope of modernization process at hand.

A number of scientific papers, reports and case studies on the modernization of irrigation schemes were analysed and quoted. The data of The Statistical Office of the Republic of 
Serbia (RZS) and The Republic Hydrometeorological Service of Serbia (RHMZ) were used as well as water legislation acts published in the Official Gazette of the Republic of Serbia (Sl. glasnik RS). The authors also consulted the World Bank Serbian Irrigation \& Drainage project' reports, business plans and project documentation of Public water management company (JVP) "Srbijavode" and field surveys of Agricultural extension service Negotin.

\section{Research results and discussion}

\section{Technical Causes for the Modernization}

The Negotin lowland, measuring 16,000 ha, is located in eastern Serbia, on the border of Serbia, Romania and Bulgaria and belongs administratively to the Negotin municipality. The boundary of the north and east is the River Danube and the downstream of the Timok river basin, from the south the mountain hinterland of Timok and Jasenička rivers, and from the west the plateau in the direction of Prahovo - Samarinovac - Miloševo - Negotin.

\section{Water availability}

Climate-related factors. Negotin lowland has a continental climate, characterized by cold winters and hot summers. Autumn is warmer than spring. Average maximum air temperature for the area of Negotin in 1981-2010 ranged from $3.9^{\circ} \mathrm{C}$ (January) to $29.7^{\circ} \mathrm{C}$ (July) and the average minimum in the range from $-3.1^{\circ} \mathrm{C}$ (January) to $16.6^{\circ} \mathrm{C}$ (July). The absolute maximum, recorded in the same period, was in July $\left(42.6^{\circ} \mathrm{C}\right)$, while the absolute minimum was in January $\left(-26.7^{\circ} \mathrm{C}\right)$. The average annual amount of rainfall is $613.6 \mathrm{~mm}$ (305.8 $\mathrm{mm}$ during the vegetation period). The average annual value of the reference potential evapotranspiration is $869.8 \mathrm{~mm}(693.9 \mathrm{~mm}$ in the vegetation period), (Table 1).

Table 1. Mean monthly values of climatic parameters in the period of 1981-2010.

\begin{tabular}{|l|r|r|r|r|r|r|r|r|r|r|r|r|r|}
\hline Parameters & I & II & II & IV & V & VI & VII & VIII & IX & X & XI & XII & God. \\
\hline Tmin, ${ }^{\circ} \mathrm{C}$ & -26.7 & -24.6 & -18.0 & -4.9 & 1.0 & 3.1 & 7.5 & 5.6 & 1.3 & -6.5 & -12.5 & -21.9 & -26.7 \\
\hline Tmax, ${ }^{\circ} \mathrm{C}$ & 21.0 & 22.4 & 26.6 & 30.6 & 35.5 & 41.2 & 42.6 & 39.3 & 37.7 & 32.5 & 25.9 & 20.6 & 42.6 \\
\hline Tmed, ${ }^{\circ} \mathrm{C}$ & 0.3 & 1.9 & 6.6 & 12.2 & 17.7 & 21.3 & 23.5 & 22.8 & 17.6 & 11.6 & 5.5 & 1.1 & 11.8 \\
\hline P, mm & 41.8 & 44.1 & 47.6 & 53.5 & 50.8 & 59.2 & 49.4 & 47.5 & 45.4 & 49.5 & 58.4 & 66.4 & 613.6 \\
\hline Insolation & 80.2 & 99.0 & 141.3 & 185.5 & 243.1 & 279.8 & 310.1 & 284.1 & 208.4 & 139.0 & 76.8 & 62.0 & 2109.2 \\
\hline R.humid, \% & 80 & 75 & 69 & 66 & 66 & 63 & 60 & 62 & 69 & 76 & 81 & 83 & 71 \\
\hline Trop. days & 0 & 0 & 0 & 0 & 2 & 8 & 16 & 16 & 3 & 0 & 0 & 0 & 44 \\
\hline Eto (mm)* & 16.6 & 22.9 & 46.9 & 78.3 & 110.2 & 135.3 & 151.7 & 130.9 & 87.5 & 48.5 & 24.5 & 16.4 & 869.8 \\
\hline
\end{tabular}

Source: RHMZ, 2012, www.hidmet.gov.rs/ciril/meteorologija/stanica sr.php?moss id=13295

Note: Period of 1971-2000, Penman Montheith method.

According to the Water Master Plan (Sl. glasnik RS, 11/2002), water needs of plants (including post-stubble cropping and intercropping) in the region of Negotin are at the level of $360 \mathrm{~mm}$. These requirements represent $80 \%$ of provision of water for all crops sowing in irrigated agriculture production system. 
In the period 1950-2005, the largest decrease in rainfall of around $120 \mathrm{~mm}$ per annum on the territory of Serbia is recorded in Negotinska Krajina ${ }^{6}$. This area is faced with more frequent and longer-lasting droughts. In 2007-2012, humidity conditions during the vegetation period, determined on the basis of the standardized precipitation index (SPI), only in one year (2008) were found to be normal. In 2007 during the growing period there was severe drought, in 2009 and 2010 drought, and in the 2011 exceptional drought, which has continued in a somewhat milder form during the winter period (severe drought category), and 2012 growing season was assessed as the period of moderate drought ${ }^{7}$.

Water resources. Hydropower potential of Negotin are rivers Danube (length $31 \mathrm{~km}$ ), Timok, Sikolska, Jasenička, Slatinska and Zamna. Internal waters in this area are scarce - the average annual flow in the basin of the Danube from Mlava to the border with Bulgaria is $51.9 \mathrm{~m}^{3} / \mathrm{s}$, while the minimum monthly flow of $95 \%$ probability is only 2.1 $\mathrm{m}^{3} / \mathrm{s}$. The Danube is the most important water source when it comes to irrigation. Danube river in the profile of Veliko Gradište is recorded an average annual flow of 5,466 m³. Minimum monthly flow of $95 \%$ probability (small monthly water) is $1,800 \mathrm{~m}^{3} / \mathrm{s}$, whereas the maximum large flow with the probability of $1 \%$ is $16,114 \mathrm{~m}^{3} / \mathrm{s}$ (Đorđević, 2009).

Water rights. The use of water for irrigation is carried out in accordance with the terms set in the water permit. Water permit regulates the manner, conditions and scope of the use of water for irrigation and shall be issued for a specified period, not longer than 15 years. The right acquired under the water permit can not be transferred to another person without the consent of the authority which issued water permit.

\section{Agronomic-related issues}

Soils. The most common type of soil in the lowland of Negotin is smonitza, which is mostly located in the cadastral municipalities (CM) of Dušanovac, Samarinovac and Prahovo and south from CM Kobišnica and CM Bukovče. Around the city Negotin and within a settlement of Miloševo, Kobišnica and Bukovče, to Timok and Danube, humogley soils and peatlands are present. Alluvial deposits are present along river flows. These soils belong to the third land capability class and with the use of agro- and hydromelioration measures provide high crop yields. Sandy soils cover Kobišnica plateau, and parts of CM Radujevac and CM Prahovo. Irrigation and fertilization increase the fertility of these soil types which is a good ground for the development of viticulture (Dinić, 1997; Hadžić et al., 2002).

Land use and production structure. According to data from 2012 Census of Agriculture, 4,658 agricultural holdings on the territory of municipality of Negotin have 30,726 ha of utilised agricultural area, of which 145 ha of kitchen garden, 21,905 ha of arable land,

6 RHMZ information about the Working Group I contribution to the IPCC Fourth Assessment Report, available at: http://www.hidmet.gov.rs/podaci/ ipcc/4 IZVESTAJ_RADNE GRUPE 1 OSNOVNI_SISTEMI \%20(SRP).pdf (in Serbian).

7 RHMZ estimation of humidity conditions in the vegetation period on the territory of Serbia based on SPI index, 2007-2012, available at: http://www.hidmet.gov.rs/ podaci/agro/SPI.pdf (in Serbian). 
465 ha of orchards, 798 ha of vineyards and 7,404 ha of meadows and pastures. There is a strong polarization in the size of holdings $-64 \%$ of holdings, which have up to 5 ha, has $21 \%$ of the total utilized agricultural land, while only $13 \%$ of holdings, which are larger than 10 ha, has $55 \%$ of the total utilized agricultural land. Agricultural holdings in the municipality of Negotin have an average of 6.54 ha of UAA divided into 9 separate lots of UAA, with average lot size of 1 ha. In addition, 10,558 ha of agricultural land owned by 2,826 agricultural holdings are abandoned due to depopulation and economic migration to Western European countries (RZS, 2013a).

On the arable fields the most common are cereals that were sown on 14,625 ha in 2012 (wheat, grain maize, oats, barley), industrial crops on 4,004 ha (sunflower) and fooder crops on 2,332 ha (lucerne, grass mixtures, clover). Favorable conditions exist for vegetables, melons and strawberries (286 ha, of which melons 191 ha) (RZS, 2013a).

On the orchards (465 ha, of which intensive plantations 199 ha) are grown apples, plums, pears, walnuts, peaches, sour cherries and blackberries (RZS, 2013a).

The Negotin vineyards (798 ha, with over twenty family wineries) have excellent relief, microclimate and pedological conditions for vine growing and a centuries old tradition of winemaking (Popović et al., 2012). Production of quality wine in drought conditions require controlled irrigation (Popović, Živanović Miljković, 2012). Krajina wine AD in early 80 s of last century began with the raising of vineyard plantation with irrigation area of 1,000 ha. Due to business difficulties during the transition they planted only 200 ha, of which 100 ha were covered by the irrigation system. In dry years in irrigated area were possible to obtain yields higher by 30-35\% than in non-irrigated area (SO Negotin, 2005).

The spacious meadow-pasture areas on the edge of the lowland (7,404 ha) enable the development of livestock grazing (51\% of goats and $44 \%$ of sheep are in grazing system compared to $25 \%$ and $24 \%$ at national level), but a long, dry and hot summers do not favor the cultivation of forage crops, nor making meadow hay (Nikolić, Popović, 2010). Animal husbandry is poorly developed (31 LU/100 ha to $59 \mathrm{LU} / 100$ ha of UAA at the national level), (RZS, 2013a).

Yields. According to the evaluation of drought impacts on the crop yields in the eastern Serbia in the period 1989-2000, the average drop in yields was $40.9 \%$, compared to the average annual yields in the years without drought (MESP, 2010). Major fluctuations in yields in recent years confirm the necessity of upgrading the irrigation system (Table 2).

Table 2. Yields of basic agricultural products, 2005-2012.

\begin{tabular}{|c|c|c|c|c|c|c|c|c|c|c|}
\hline \multirow{3}{*}{ Culture } & \multicolumn{5}{|c|}{ Municipality of Negotin } & \multicolumn{5}{|c|}{ Republic of Serbia } \\
\hline & \multicolumn{3}{|c|}{$2005-2010$} & \multirow{2}{*}{2011} & \multirow{2}{*}{2012} & \multicolumn{3}{|c|}{$2005-2010$} & \multirow{2}{*}{2011} & \multirow{2}{*}{2012} \\
\hline & MIN & MAX & AVER & & & MIN & MAX & AVER & & \\
\hline $\begin{array}{l}\text { Wheat, } \mathrm{kg} / \mathrm{ha} \\
\text { Family farms } \\
\text { Legal entities and coop. }\end{array}$ & $\begin{array}{l}1,400 \\
1,200\end{array}$ & $\begin{array}{l}3,596 \\
3,909\end{array}$ & $\begin{array}{l}2,952 \\
2,512\end{array}$ & $\begin{array}{l}3,574 \\
3,846\end{array}$ & $\begin{array}{l}3,429 \\
2,000\end{array}$ & $\begin{array}{l}3,060 \\
4,202\end{array}$ & $\begin{array}{l}4,068 \\
5,278\end{array}$ & $\begin{array}{l}3,388 \\
4,469\end{array}$ & $\begin{array}{l}3,943 \\
5,652\end{array}$ & $\begin{array}{l}3,719 \\
5,303\end{array}$ \\
\hline
\end{tabular}




\begin{tabular}{|c|c|c|c|c|c|c|c|c|c|c|}
\hline \multirow{3}{*}{ Culture } & \multicolumn{5}{|c|}{ Municipality of Negotin } & \multicolumn{5}{|c|}{ Republic of Serbia } \\
\hline & \multicolumn{3}{|c|}{$2005-2010$} & \multirow{2}{*}{2011} & \multirow{2}{*}{2012} & \multicolumn{3}{|c|}{$2005-2010$} & \multirow{2}{*}{2011} & \multirow{2}{*}{2012} \\
\hline & MIN & MAX & AVER & & & MIN & MAX & AVER & & \\
\hline $\begin{array}{l}\text { Maize, } \mathrm{kg} / \mathrm{ha} \\
\text { Family farms } \\
\text { Legal entities and coop. }\end{array}$ & $\begin{array}{r}1,006 \\
700\end{array}$ & $\begin{array}{l}5,358 \\
6,250\end{array}$ & $\begin{array}{l}3,739 \\
3,758\end{array}$ & $\begin{array}{l}3,936 \\
3,000\end{array}$ & $\begin{array}{l}2,447 \\
7,713\end{array}$ & $\begin{array}{l}3,037 \\
5,117\end{array}$ & $\begin{array}{l}5,723 \\
7,494\end{array}$ & $\begin{array}{l}4,862 \\
6,664\end{array}$ & $\begin{array}{l}4,948 \\
7,399\end{array}$ & $\begin{array}{l}2,697 \\
3,735\end{array}$ \\
\hline Sunflower, $\mathrm{kg} / \mathrm{ha}$ & 788 & 2,472 & 2,008 & 2,239 & 1,752 & 1,773 & 2,419 & 2,132 & 2,479 & 2,193 \\
\hline Beans, $k g / h a$ & 100 & 1,038 & 678 & 930 & 591 & 947 & 1,294 & 1,159 & 1,183 & 808 \\
\hline Potato, $\mathrm{kg} / \mathrm{ha}$ & 3,553 & 5,991 & 4,915 & 5,636 & 4,148 & 9,134 & 11,573 & 10,835 & 11,375 & 7,660 \\
\hline Clover, $\mathrm{kg} / \mathrm{ha}$ & 2,142 & 3,614 & 2,795 & 2,227 & 1,598 & 3,539 & 4,536 & 4,290 & 4,020 & 3,163 \\
\hline Lucerne, $\mathrm{kg} / \mathrm{ha}$ & 2,868 & 4,337 & 3,514 & 2,638 & 1,865 & 4,797 & 6,003 & 5,639 & 5,320 & 4,032 \\
\hline Meadows, $\mathrm{kg} / \mathrm{ha}$ & 830 & 1,595 & 1,264 & 1,977 & 751 & 1,476 & 2,055 & 1,827 & 1,841 & 1,333 \\
\hline Pasture, $\mathrm{kg} / \mathrm{ha}$ & 351 & 636 & 490 & 955 & 607 & 487 & 773 & 596 & 669 & 487 \\
\hline Apples, $k g$ /tree & 30.9 & 40.6 & 34.8 & 35.2 & 17.7 & 13.4 & 18.1 & 15.8 & 16.6 & 10.6 \\
\hline Plums, $k g /$ tree & 17.2 & 25.1 & 19.6 & 18.3 & 13.0 & 7.1 & 16.2 & 12.9 & 14.3 & 9.7 \\
\hline Grape, $k g /$ tree & 0.7 & 2.1 & 1.4 & 1.9 & 1.3 & 0.7 & 1.5 & 1.1 & 1.2 & 1.0 \\
\hline
\end{tabular}

Sources: RZS. Municipalities of Serbia 2006-2009, Belgrade, 2007-2010; RZS. Municipalities and regions of the Republic of Serbia 2011-2013, Belgrade, 2011-2013.

Irrigation. Studies have shown that in the local climatic conditions and with the application of appropriate agricultural inputs and techniques, irrigation can increase yields by 50 to $80 \%$, and in the years with a severe drought for 2 to 4 times in some crop species (Dragović, 2001; Maksimović, Dragović, 2004; Obradović et al., 2012).

According to 2012 Agricultural Census, 459 agricultural holding in Negotin municipality irrigated 410 ha (1.3\% of UAA), of which 357 ha of arable land (vegetables, melons and strawberries in outdoor conditions 166 ha, cereals and maize for fodder 154 ha, sunflower 19 ha), 41 ha of fruit plantations, 3 ha of vineyards and 9 ha of other permanent crops. The most common irrigation method is surface irrigation (62.6\% of irrigated area), then drop irrigation (24.2\%) and sprinkler irrigation (13.1\%). Main water sources for irrigation are groundwater (49.9\%) and surface water outside holding (34.8\%), (RZS, 2013a).

\section{Hydromelioration infrastructure}

Of the total area covered by the Negotin lowland, 11,800 ha can be irrigated. This area is divided into two altitude zones. The higher altitude zone includes Kobišnica plateau altitude 40-80 m (CM Kobišnica and CM Bukovče) and the area west of the line Prahovo - Samarinovac - Miloševo with the altitude of 60 to 120 meters. Lower altitude zone, with an altitude of approximately 30-40 m covers the rest of the Negotin lowland. Land consolidation in this area was completed in 1985 year, except in CM Srbovo and CM Radujevac, and during this process the area for hydro-system completion was reserved.

Pilot project for construction of hydro-system for irrigation of Negotin lowland (1977) was based on the use of the existing pump station IHP "Prahovo", consists of three mutually independent systems - pumping stations (PS): "Kusjak", "Radujevac" and "Kosno Grlo III", and is designed to cover an area of 1,100 ha of arable land dominantly owned family farms. The hydro-system consists of a main pipeline length of $13,500 \mathrm{~m}$ constructed of steel pipe of different diameters $(600-250 \mathrm{~mm})$. Secondary piping that carries water to the 
end users are built of PE pipes of different diameters (250-125 mm). Audit of the project by the "Hidroinvest DTD" in the Novi Sad (JVP "Srbijavode", 1996) were consolidated three existing independent systems in a distribution system. Basic approach in the choice of technical solution is the creation of a ring network as the basic skeleton of the distribution network which brings water to the secondary connections. This helps ensure consumer participation along the whole system in investment in the system as a whole. Source of water supply is the river Danube.

Advantage of the system is the construction in stages. So far, there have been built 9 secondary pipelines with total length of 6,450, and also 79 hydrant heads diameter 125 and $100 \mathrm{~mm}$. One hydrant head covers three to five parcels depending on the size of parcel. The pipeline's operating pressure of 2.5 bar which gives farmers a wide variety of irrigation equipment. On the systems there are built other facilities - flow meters, valves, drains, manholes, etc. (DD “'HIDROINVEST' DTD, 1996).

According to Spatial plan of Negotin municipality (S1. list opštine Negotin, 16/2011), planned works on the extension of Hs Negotin lowland, covering all 11,800 hectares suitable for irrigation, have been divided into three phases. The first phase of construction is PS "Kusjak", capacity of $5 \mathrm{~m}^{3} / \mathrm{s}$, upstream of the Kusjak dock, with pressure piping and basins in the hilly zone of Dušanovac. The construction of PS "Kusjak" with tank and distribution network would ensure irrigation of $70 \%$ above areas. However, the first phase includes the construction of $38 \%$ of maximum capacity consumption, meaning 1,560 1/s. At this level of development management system is simple since the charge piping is done from an open reservoir by gravity. A further demand for water will result in a pressure drop in the network and the need to involve in work PS "Kosno Grlo III." PS "Kosno Grlo III", capacity of $2 \mathrm{~m}^{3} / \mathrm{s}$ will enable the irrigation of 3,744 hectares in the two altitude zones and its construction is planned in the second phase, in addition to the existing drainage pumping stations, while the tanks, the ground conditions were located about $2.7 \mathrm{~km}$ from the pumping station. The third phase will be PS "Radujevac" upstream from Radujevac a capacity of $1.5 \mathrm{~m} / \mathrm{s}$, with pressure pipeline to the tank, length $500 \mathrm{~m}$, and allow irrigation of 1999 ha in the upper parts of the area. Upon completion of the irrigation Negotin lowland it would be secured to the pressure in the pipe from 5 bar and could be used by various modes of irrigation that meets the designed pressure.

\section{Water management}

Law on Waters (Sl. glasnik RS, 30/2010) found that Republic of Serbia realizes water management through relevant ministries, provincial and local administrations and public water management companies (PWMC). Lower Danube water area, which comprises the Hs Negotin lowland is in the responsibility of the PWMC "Srbijavode".

Public water management companies in water areas for which they are responsible, manage water resources and adjusted the water needs of different users; monitor, maintain and improve the water regime; manage water facilities for rivercources regulation and flood protection; menage drainage structures in public ownership, dams with reservoirs, locks on the canals and irrigation systems; organize and implement measures of protection from 
erosion, torrents and water pollution; prepare programs, plans and technical documentation, take care of water management information system and perform the obligations of international cooperation in the field of water management.

Public water management companies entrusted part of the maintainance works on water facilities to water management enterprises, organized largely on the territorial principle. With these enterprises public water management companies enter into long-term contracts for technical cooperation. Lack of funding in the last two decades has seriously jeopardized the functioning of the water management system in Serbia.

\section{Socio-institutional Causes for the Modernization}

\section{Human resources}

Outflow of residents abroad is characteristic of the municipality of Negotin. A large number of young people are living and working in Western Europe. According to the preliminary results of the Census of 2011, in addition to 36.879 residents, abroad is still 12,427 persons. The people abroad in a number of settlements, primarily in economically most vibrant areas called Danube Valley's development belt, exceed the number of those who live in them (Dušanovac, Mala Kamenica, Slatina, Mihajlovac). It is required a more active role of the state, local communities and associations of producers to encourage returnees from abroad to invest in agriculture and irrigation (RZS, 2011).

Holding population. The most members of agricultural holding in the municipality of Negotin are situated on the family farms (99\%). The number of members per holding and educational structure of the holding managers are a serious development constraint. Although this is about slightly larger holdings than the national average ( 6.5 ha compared to 5.4 ha at the national level), just a small number of persons live and work there (68\% of agricultural holdings have 1-2 persons and 28\% have 3-4 persons), with low level of education (78.2\% of holding managers have only practical agricultural experience, $0.3 \%$ agricultural courses, $3 \%$ have secondary agricultural school, college or faculty, and 18\% other secondary school, college or faculty), (RZS, 2013a).

Farmer associations. Association of producers is necessary to overcome the existing limitations, which greatly hinder the development of profitable farming (small property, shortness of supply of inputs, low bargaining power of farmers in the purchase, lack of storage and processing facilities, the introduction of quality standards and branding, etc.). Negotin municipality has a century old tradition of cooperatives. Today, operate agricultural cooperatives: "Oilseeds" Negotin, "Prahovo" and "Jeremić" LTD, Prahovo, "Dinković" Kovilovo, "Poljokop" Jabukovac, "Radujevac", Radujevac, and "Spring" Šarkamen; specialized fruit-viticulture-vine cooperative in Smedovac and "Krajinska wine cooperative" Rogljevo; and agricultural associations of winemakers of Negotinska krajina, of fruit growers in Karbulovo, of livestock breeders of the municipality of Negotin and of beekeepers "Hajduk Veljko" in Negotin (SO Negotin, 2012).

Extension service. The main activity of the Agricultural extension service Negotin is the transfer of knowledge and the provision of advisory services to farmers, related to the use 
of resources and inputs in agriculture (fertilizer and pesticide use, control of seeds and plant materials quality, etc.). When it comes to irrigation, it is necessary, guided by the international experiences, to provide specialized consulting services in the area, either as a separate service, or a special section of the existing agricultural extension services, which would be financed from the budget or co-financed by the water users. Annual development program for advisory services in agriculture in 2014 (Sl. glasnik RS, 34/2014) stipulates for 5 of the 22 regional agricultural extension services the obligation of engaging advisors for meliorations, but not for Negotin agricultural extension service.

\section{Water users' associations}

FAO defines irrigation management transfer as a (full or partial) reallocation of responsibility and authority for management of irrigation systems from government agencies to nongovernmental organizations such as water users' associations (WUAs) at irrigation system or subsystem levels (Vermillion, Sagardoy, 1999).

World Bank's experts defined the process of institutional reforms in irrigation as a continuum of reducing government involvement and increasing participation by user associations and private sector service providers, where the attention should shift from individual institutional model to the the mix of models that can offer the best water service (Darghouth, 2007).

The WUA usually governs and manages the system directly up to the tertiary or distributary level and in this case appoints or hire a few technically competent full time staff for seasonal work on water distribution, channel cleaning and collecting water charges. At higher hydraulic levels, it is common for WUAs (or Federation of WUAs) to handle only governance or oversight functions, while professional staff of WSP company owned or contracted by WUA handle operation and maintenance (O\&M) service ${ }^{8}$. In order for the activities of WUAs to be economically viable it may be considered the formation of multifunctional WUAs, who would financed part of the O\&M service costs with the profit from the secondary activities (provision of agricultural inputs, agricultural processing and marketing, etc.). WUAs or Federations of WUAs can also play a role in environmental policy advisory bodies (Garces-Restrepo et al., 2007).

Law on Waters (2010) regulates, in accordance with the separate law, the establishment of water users' associations of the interested parties in the melioration area or part thereof in order to provide conditions for various types of water uses and protection from the damaging effects of water. Law on WUAs in agriculture (draft) is primarily oriented to the establishment and operation of WUAs that will govern and manage minor irrigation schemes in order to ensure coverage of small holdings with irrigation systems and the legalization of the use of water for irrigation by these farms. ${ }^{9}$

8 Including delegation of all the transferable irrigation and drainage functions to a third party under various forms of longterm public-private partnership arrangement (Darghouth, 2007).

9 Draft Law on water users' organizations in agriculture, available at: http:/www.rdvode.gov.rs/ javne-rasprave.php (in Serbian). 
The draft law provides the possibility of the formation of the Federations of WUAs. The experiences and views of countries with a developed network of WUAs confirm that better irrigation services and participation in decision making will only be possible by federating WUAs at scheme level to provide representation in the river basin councils, as basis for real irrigation management decentralization (Tusa et al., 2007).

Institutional Strengthening and Capacity Building component of World Bank Irrigation and Drainage Rehabilitation Project in Serbia comprises activities related to WUAs establishment. Draft WUAs Law has been prepared and publicly disclosed and discussed during 2013, and 28 WUAs are supported and fully established thus laying grounds for further activities in this area in the irrigation sector (World Bank, 2014).

\section{Financial/Economic causes}

\section{Water tariff structure and irrigation sector financing}

The concept of full costrecovery requires that water prices reflect the financial, environmental and resource costs of supplying water. Including concept of full cost recovery in agriculture is very complex. A key challenge lies in establishing water pricing that minimises impacts on farm income but incentivises water conservation and recovers a larger share of costs, including those related to environmental degradation (EEA, 2012).

As a result of the global economic crisis and associated budget restrictions, the budget appropriations and funds for the irrigation sector are reducing and there is a growing pressure to increase user involvement in the financing of O\&M and capital costs of irrigation. This policy must be accompanied by the transfer of management to WUAs and increased transparency of water service providers, and implemented in terms of increasing profitability of irrigated agriculture (Svendsen, Turral, 2007).

Among the different agricultural water pricing mechanisms in Europe, the most common are the two-part tariff (combining a flat rate and a unitary volumetric rate), and the tariff based on the irrigated area (Ecologic, 2007). The fee based on a single price per unit of water is considered the first choice in terms of water savings, but it is rarely used due to the high cost of water metering. The effects of pricing policies on water demand and water savings depend on the price elasticity i.e. profitability of irrigated crops.

Water charges in Serbia are defined by the Law on Waters, and the amount per annum determined by government regulation. The area encompassing the Negotin lowland, provided the following charges for irrigation:

The charge for use of water resources. Payer is a legal entity, entrepreneur or individual, that pays the use of water for irrigation according to the volume of water $\left(\mathrm{RSD} / \mathrm{m}^{3}\right)$, where there are devices for measuring the amount of water, or according the irrigated area (RSD/ ha), where mention equipement do not exist.

The charge for use of water facilities and hydro-systems. Payer is the owner/user of agricultural and forest land, which uses water facilities and irrigation systems in public ownership, and the tariff is two-part: fixed component, based on installed capacity (RSD/ 
ha) and variable, based on engaged capacity - volumetric $\left(\mathrm{RSD} / 1000 \mathrm{~m}^{3}\right)$, or based on irrigated area, if there is no measuring device (RSD/ha).

User of water supplied through the high-pressure pumping station pays additional charge $(\mathrm{RSD} / \mathrm{l} / \mathrm{s})$ of installed capacity of the pumping station used for his irrigated area.

If the equipement used are parts of the regional irrigation systems (such as Hs Negotin lowland), additional two-part tariff is charged - according the installed capacity (RSD/ha), and the engaged capacity ( $\mathrm{RSD} / 1000 \mathrm{~m}^{3}$ or $\mathrm{RSD} /$ ha where there is no measurement device).

For the implementation of the project of rehabilitation, modernization and upgrading of irrigation systems, in addition to budgetary appropriations significant funding from foreign sources of financing are expected (IBRD/IDA, UAE). The use of these funds is conditioned by ensuring the relevant technological, and institutional requirements in terms of environmental protection in the water management sector, as well as economic conditions in the sector of irrigated agriculture.

\section{Agricultural profitability}

Irrigation allows higher cropping intensities (intercropping, etc.) and diversification of agricultural production toward higher value crops and niche products (fruits and vegetables, vinegrapes, etc.), thus providing stabilization and growth of farmers' income, foster entrepreneurship and producer associations and rise overall rural economy.

Calculating the margin of coverage based on the variable costs for different types of plant production serve as a basis for economic analysis and business planning on farm, in order to obtain high-quality products with the lowest possible production costs. The calculation based on the variable costs enables direct comparison of the financial performance of two different lines or phases of crop production with equal fixed costs, and a comparison of two or more different intensities of the same lines or phases of crop production (Subic et al., 2010). Margin coverage is defined as the difference between the total value of production (value of the base product plus the value of by-products and subsidies) and proportionate variable costs, and in mathematical form is represented by the formula:

$$
M C_{\text {(margin of coverage) }}=V P_{\text {(value of production) }}-V C_{\text {(variable costs). }}
$$

Regarding structure of agricultural production in Negotin lowland and using calculations cover margins based on the variable costs, in the analysis below a contribution of irrigation to yield and profitability increases in production of corn, potatoes and watermelon was evaluated. ${ }^{10}$ In different production lines different effects achieved. However, common to all crops analysed is the increase in yields (revenue and profit growth) due to the application of irrigation, whose costs have not significantly affected the total amount of variable costs (Table 3 ).

10 Calculations are based on Agricultural extension service Negotin data of annual value of production and production costs per hectar, realised on family farms in settlements: Prahovo, Rečka and Čubra during production year 2011/2012. 
Table 3. Margin of coverage based on the variable costs - the effects of irrigation

\begin{tabular}{|c|c|c|c|c|c|c|}
\hline \multirow{2}{*}{ Opis } & \multicolumn{2}{|c|}{ Corn } & \multicolumn{2}{|c|}{ Potato } & \multicolumn{2}{|c|}{ Watermelon } \\
\hline & (EUR/ha) & $\%$ & (EUR/ha) & $\%$ & (EUR/ha) & $\%$ \\
\hline \multicolumn{7}{|c|}{ Calculations without irrigation } \\
\hline $\mathrm{VP}_{0}$ (Value of production) & 830.85 & & 1826.06 & & $2,002.98$ & \\
\hline $\mathrm{VT}_{0}$ (Variable costs) & 444.53 & & 1363.89 & & $1,959.10$ & \\
\hline $\mathrm{MP}_{0}$ Margine of coverage $\left(\mathrm{VP}_{0}-\mathrm{VT}_{0}\right)$ & 386.32 & & 462.17 & & 43.88 & \\
\hline \multicolumn{7}{|c|}{ Calculations with irrigation } \\
\hline $\mathrm{VP}_{1}$ (Value of production) & $1,604.90$ & & $5,364.58$ & & $4,922.26$ & \\
\hline $\mathrm{VT}_{1}$ (Variable costs) & 558.84 & & $1,483.59$ & & $2,078.72$ & \\
\hline $\mathrm{MP}_{1}$ Margine of coverage $\left(\mathrm{VP}_{1}-\mathrm{VT}_{1}\right)$ & $1,046.06$ & & $3,880.98$ & & $2,843.54$ & \\
\hline \multicolumn{7}{|c|}{ Calculation of the effect of irrigation } \\
\hline $\mathrm{VP}_{1}-\mathrm{VP}_{0}=\mathrm{VP}_{\mathrm{p}}($ Revenue increase $)$ & 774.05 & 93.16 & $3,538.52$ & 193.78 & $2,919.28$ & 145.75 \\
\hline $\begin{array}{l}\mathrm{VT}_{1}-\mathrm{VT}_{0}=\mathrm{VT}_{\mathrm{p}}(\text { Increase in variable costs) } \\
=\mathrm{Tn} \text { (Irrigation costs) }\end{array}$ & 114.31 & 25.71 & 119.71 & 8.78 & 119.62 & 6.11 \\
\hline $\mathrm{MP}_{1}-\mathrm{MP}_{0}=\mathrm{MP}_{\mathrm{p}}($ Increase in profit $)$ & 659.74 & 170.78 & $3,418.82$ & 739.74 & $2,799.66$ & $6,380.61$ \\
\hline
\end{tabular}

Source: Author's contribution based on: Gavrilović, (2012).

Analyzing the effects of irrigation on selected crops, leads to the following observations:

- In corn production, irrigation has caused:

- Growth of $100.00 \%$ yield and increase the production value of $93.16 \%$;

- Increasing the overall value of the variable costs of $25.71 \%$;

- $\quad$ Increase in profits by over $170 \%$.

- In potato production, irrigation has occurred:

- $\quad$ Growth of $200.00 \%$ yield and increase the production value of nearly $194 \%$;

- $\quad$ Increase in total variable costs of $8.78 \%$;

- $\quad$ Increase in profits of $739.74 \%$.

- In watermelon production, irrigation has achieved:

- $\quad$ Growth of $150.00 \%$ yield and increase in production by over $145 \%$;

- Increase in total variable costs for $6.11 \%$;

- $\quad$ Increase profits by $6,380.61 \%$.

Given the specific examples, it can be said that irrigation contributes significantly to the growth of the profitability and competitiveness of the family farm. Given the costs, irrigation also leaves plenty of room for after covering variable costs, the remaining funds cover fixed costs and achieve positive financial results.

\section{Environmental causes}

\section{Soil Degradation}

Irrigation regulates water-air regime of soil and increase yields. However, despite all the positives, irrigation also has a negative consequences related to soil and ecosystems. Given the geological structure and the hydrological and pedological 
characteristics of Negotin lowland, the most common problems that occur due to improper application of irrigation and its application in unsuitable conditions are:

Waterlogging. There is increasing the level of ground water in the plant root zone and creates anaerobic conditions. The lack of oxygen causes the plants have delayed growth, yellow and die. This problem is most commonly regulated by drainage or application of other agri-melioration measures.

Salinization and alkalinization. Salinization is the process of accumulation of harmful salts in the surface soil layer. The reasons for this may be use for many years of irrigation water with high content of harmful salts, or taking salt from underground mineralized water. Dominated by sodium ions occurs alkalization process that contributes to poor water-physical and chemical properties of the soil. Raising the level of groundwater that leading to waterlogging process, can also lead to salinization and alkalization in the case of groundwater with higher concentration of salt.

Nutrient leekeage. It occurs when intensive irrigation cause nutrients descending in the deeper soil layers, impoverishing the soil and reducing its production capacity. This problem is usually solved by appropriate crop rotation, fertilization and adequate treatment of the land. From the perspective of the irrigation, this problem can be solved by proper setting of time and quantity of irrigation, thus reducing the deterioration of water-physical properties of soil and irrigation erosion phenomenon.

Irrigation erosion. Most common in surface irrigation methods (furrow and overflow). It can occur in sprinkling irrigation on sloping terrain and when the intensity of rain is not in accordance with the process of infiltration into the soil. Directly dependent on soil structure, so improvement of the structure and stability of soil structural aggregates prevents irrigation erosion.

Ecosystem Conservation. At sites where irrigation is applied there is increasing diversity and biomass of plants and insects, which can result in proliferation of insects harmful to crops (beetles, corn root worm, etc).

\section{Conclusions}

Economy of Negotin lowland is dependent on agriculture and agricultural productivity depends to a great extent on the construction of irrigation systems.

According to data of the Agricultural extension service Negotin, farmers who have used irrigation system in Negotin lowland during the previous decade testify of 2-5 times increased yields of some crops in relation to the average achieved in non-irrigated production.

Investing in the irrigation system construction is based on the existence of adequate technical, social, institutional, economic, financial and environmental conditions which have been discussed earlier in the text. The main benefits and constraints of Hs Negotin lowland construction will be summarized below. 
Advantage of Hs Negotin lowland is the construction in stages. Agricultural Land Department of the Ministry of Agriculture has approved 113.7 million dinars to PWMC "Srbijavode" for the construction of irrigation system on 700 ha on the Negotin lowland in 2014. Thus, with the existing 450 ha will be completed pilot irrigation system "Prahovo" in the area of 1,150 ha, that started two decades ago.

To justify the investment it is necessary that a sufficient number of landowners and land users declare their intention to use the water from the irrigation system and, organized in a water users' association, participate in irrigation management.

Population decline and lack of funding are the major obstacle for efficient use of irrigation in agriculture in Negotin lowland. The construction of irrigation system as well as the budgetary support to irrigated agriculture and to entrepreneurship in agriculture and rural tourism can be a triggers for the decision of local farmers and entrepreneurs as well as of the people abroad to return home and invest their savings in agriculture, including the purchase of irrigation equipment.

Farmers and WUAs may use budgetary subsidies to irrigation in the frame of annual Program of work on protection, reclamation and use of agricultural land for the purchase of equipment for irrigation systems (compensation of $100 \%$ costs of constructing water intake and the primary network and subsidization interest on bank loans for the purchase of irrigation equipment). Budget funds intended for rural development support, cofinanced drip and sprinkler irrigation systems for the vegetable growers in the open.

Institutional constraints are also present. There is a delay in the adoption of the Law on water users' organizations in agriculture as well as poor results in the privatization of water management enterprises. The proposed nationalization of water management enterprises and the formation of weak WUAs, in the absence of complete legislative support, does not refer to progress in reducing the role of government in the management of irrigation for the benefit of water users associations and private water service providers.

Urgent action by the state, regional development agencies and local stakeholders is necessary in animation of local population and fostering revitalization of cooperatives and associations of producers and water users as well as additional involvement of extension services in irrigation. Agricultural extension service Negotin, covering the territory of municipalities Negotin, Bor, Kladovo and Majdanpek, has no advisor in the field of meliorations.

Considering the level and expected rise in water charges and in the rate of their collection on the one hand, and the higher yields in irrigated agriculture on the other, irrigation should be efficient, environmentally appropriate and profitable. It is not necessary to emphasize the importance of production structure adjusting and proper market analysis for farmer's decision-making related to irrigation. 
Cross-border and regional cooperation and exchange of experience is definitely a great help in the process of technical and managerial upgrading of irrigation schemes and related institutional reforms.

Main results of the analysis of causes for upgrading Hs Negotin lowland summarized here support the decision on its construction, on a comprehensive basis, which includes socio-institutional improvements and fulfillment of appropriate economic-financial and environmental conditions, according to FAO concept of irrigation modernization.

\section{Literature}

1. Darghouth, S. (2007): Emerging Public-Private Partnerships In Irrigation Development and Management, The World Bank, Water Sector Board Discussion Paper Series: Paper No. 10.

2. DD “'HIDROINVEST" DTD (1996): Hidrosistem za navodnjavanje dela Negotinske nizije korišćenjem postojeće pumpne stanice IHP Prahovo, Novi Sad.

3. Dinić, J. (1997): Prirodni potencijal Srbije. Ekonomsko-geografska analiza i ocean, Beograd, Ekonomski fakultet.

4. DMCSEE - Drought Management Centre for South East Europe (2011): E-newsletter 02, February 2011.

5. Dragović, S. (2001): Potrebe i efekti navodnjavanja na povećanje i stabilizaciju prinosa u poljoprivrednim područjima Srbije, Zbornik radova Instituta za ratarstvo i povrtarstvo, br. 35 , str. $445-456$.

6. Đorđević, B. (2009): Korišćenje vodnih resursa, Strategija prostornog razvoja Republike Srbije, Studijsko-analitička osnova, IAUS, Beograd.

7. Ecologic (2007): EUwater saving potential, Part 1, Report, available at: http://ec.europa. eu/environment/ water/ quantity/pdf/water_saving_1.pdf

8. European Environment Agency - EEA (2012): Towards efficient use of water resources in Europe, EEA Report, No. 1/2012.

9. Garces-Restrepo, C., Vermillion, D., Muñoz, G.(2007): Irrigation Management Transfer. Worldwide efforts and results, FAO Water Reports: 32, Rome.

10. Gavrilović, V. (2012): Bruto marže 2012, Poljoprivredna stručna služba Negotin d.o.o., Negotin, Interna dokumentacija.

11. Hadžić, V., Nešić, Lj., Belić, M., Furman, T., Savin, L. (2002): Zemljišni potencijal Srbije, Traktori i pogonske mašine, vol. 7:4/2002, pp. 43-51.

12. Institut za vodoprivredu “Jaroslav Černi" - IJČ (2001): Vodoprivredna osnova Republike Srbije, IJČ, Beograd.

13.IPCC (2007): Climate Change 2007: Impacts, Adaptation and Vulnerability. Working Group II Contribution to the IPCC Fourth Assessment Report. Summary for Policymakers, IPCC, Brussels. 
14. IPTRID/FAO-AGLW Collaborative Initiative (2002): Survey on modernization of irrigation schemes, available at: http:/www.fao.org/nr/water/topics_irrig_modernis. html

15. JVP "Srbijavode” (2014): Program poslovanja za 2014. godinu, Beograd.

16.JVP "Srbijavode" (1996): Hidrosistem za navodnjavanje dela Negotinske nizije korišćenjem postojeće pumpne stanice IHP "Prahovo”, Idejni i glavni projekat, Beograd.

17.Maksimović, L., Dragović, S. (2004): Water requirements of field crops and effects of irrigation, Acta biologica Iugoslavica - serija A: Zemljište i biljka, vol. 53, no. 2, pp.85-92.

18. Ministry of Environment and Spatial Planning - MESP (2010): Initial National Communication of the Republic of Serbia under the United Nations Framework Convention on Climate Change, MESP, Beograd.

19. Nikolić, M., Popović, V. (2010): The Possibility of Safe Food Production in Protected Areas, XIV International Eco-Conference, September 2010, Proceedings, Ecological Movement of Novi Sad, pp. 199-206.

20. Obradović, D., Teofanović, Ž., Petrović, P., Petrović, M., Ružičić, L. (2012): Značaj i uticaj navodnjavanja na naturalni i ekonomski efekat poljoprivrednih prinosa, Traktori i pogonske mašine, Vol. 17, br. 5, str. 46-53.

21.Popović, V, Sarić, R., Jovanović, M. (2012): Sustainability of Agriculture in Danube Basin Area, Economics of Agriculture, Vol. LIX, No.1, pp. 73-87.

22.Popović, V., Živanović Miljković, J. (2012): Wine Tourism and Sustainable Rural Development in the Danube Basin Area in Serbia, International Scientific Meeting Sustainable agriculture and rural development in terms of the Republic of Serbia strategic goals realization within the Danube region - preservation of rural values, Tara, December 2012, IAE, Belgrade, Thematic proceedings.

23. Republički zavod za statistiku - RZS (2014): Navodnjavanje u Republici Srbiji, 2013, Prethodni rezultati, Saopštenje br. 099, God. LXIV, 25.04. 2014.

24. Republički zavod za statistiku - RZS (2011-2013): Opštine i regioni u Republici Srbiji 2011-2013, RZS, Beograd.

25.Republički zavod za statistiku - RZS (2013a): Popis poljoprivrede u Republici Srbiji 2012, Baza podataka, available at: http://popispoljoprivrede.stat.rs/popis/wp-content/ themes/popis2012/sadrzajcir.htm

26. Republički zavod za statistiku (2011): Popis stanovništva, domaćinstava i stanova u Republici Srbiji 2011, Prvi rezultati, Bilten 540, Beograd.

27. Republički zavod za statistiku (2007-2010): Opštine u Srbiji 2006-2009, RZS Beograd.

28. SO Negotin (2012): Strategija održivog razvoja opštine Negotin za period 2012-2021. godine, SO Negotin, Srbija.

29.SO Negotin (2005): Program razvoja opštine Negotin za period 2005-2010. godine, SO Negotin, Srbija. 
30. Subić, J., Ivanović, L., Jeločnik, M. (2010): The impact of incentives on the cover variable costs in the production of field crops, PKB Scientific Meeting, Proceedings, Vol. 16, no.1-2, pp. 251-264.

31. Svendsen, M., Turral, H. (2007): Reinventing irrigation, In Molden, D., ed. Water for food, water for life: A Comprehensive Assessment of Water Management in Agriculture, London, UK: Earthscan; Colombo, Sri Lanka: IWMI, pp. 353-394.

32. The World Bank (2014): Irrigation\&Drainage Rehabilitation Project (Serbia): Implementation Status \& Results, Report No: ISR 13788, 29-Mar-2014, Final Project Implementation Status Report.

33. Tusa, C., Paraschiv, D., Badulescu, F., Redulescu, A. (2007): Experiences on Water Users' Associations Development in Romania, In Hussain, I., Zeeshan, N, eds., Water Users' Associations Development in Southeastern European Countries: Regional Workshop on WUAs Development, June, 2007, Bucharest, Proceedings.

34. UN (2011): Water and Agriculture in the Green Economy, Information Brief, United Nations Office to support the International Decade for Action 'Water for Life' 20052015/UNW-DPAC.

35. Vermillion, D., Sagardoy, J. A. (1999): Transfer of irrigation management services, Guidelines, FAO Irrigation and Drainage Paper no. 58, FAO, Rome.

36. Wolters, H. W., Burt, C. M. (1997): Concepts of Modernization, In Modernization of Irrigation Schemes: Past Experiences and Future Options, FAO Water Reports: 12, FAO, Rome. 


\title{
DOGRADNJA SISTEMA ZA NAVODNJAVANJE NEGOTINSKE NIZIJE ${ }^{11}$
}

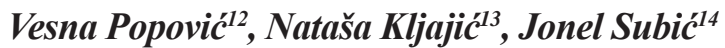

\section{Rezime}

Prema FAO konceptu modernizacije navodnjavanja, da bi bio rentabilan, sistem za navodnjavanje mora biti zasnovan na poboljšanoj efikasnosti, smanjenju operativnih troškova $i$ troškova održavanja, $i$ unapređenom povraćaju troškova zasnovanom na rastućoj produktivnosti u poljoprivredi, uz posvećivanje dužne pažnje institucionalnim $i$ zakonodavnim pitanjima $i$ zaštiti životne sredine. Uspešna modernizacija sistema za navodnjavanje pretpostavlja sveobuhvatnu analizu faktora koji vode modernizaciji.

Koristeći IPTRID/FAO-AGLW metodološki pristup za analizu faktora modernizacije sistema za navodnjavanje, autori u radu razmatraju tehničke, socio-institucionalne, ekonomskofinansijske i ekološke uslove za dogradnju sistema za navodnjavanje u Negotinskoj niziji i daju određene preporuke za uspešnu realizaciju ovog projekta, na osnovu međunarodnih i regionalnih iskustava u ovoj oblasti, prilagođenih specifičnostima lokalne poljoprivrede $i$ ruralnih zajednica.

Ključne reči: modernizacija sistema za navodnjavanje, profitabilnost poljoprivrede $u$ uslovima navodnjavanja, udruženja korisnika voda.

11 Rad predstavlja deo istraživanja u okviru projekta III 46006 - Održiva poljoprivreda i ruralni razvoj u funkciji ostvarivanja strateških ciljeva Republike Srbije u okviru Dunavskog regiona, finansiranog od strane Ministarstva prosvete, nauke i tehnološkog razvoja Republike Srbije u projektnom periodu 2011-2014.

12 Dr Vesna Popović, naučni savetnik, Institut za ekonomiku poljoprivrede, Volgina 15, 11060 Beograd, Srbija, Telefon: +381 116972 858, E-mail: vesna_p@,iep.bg.ac.rs

13 Dr Nataša Kljajić, naučni saradnik, Institut za ekonomiku poljoprivrede, Volgina 15, 11060 Beograd, Srbija, Telefon: +381 116972 858, E-mail: nataša k@iep.bg.ac.rs

14 Dr Jonel Subić, viši naučni saradnik, Institut za ekonomiku poljoprivrede, Volgina 15, 11060 Beograd, Srbija, Telefon: +381 116972 858, E-mail: jonel_s@,iep.bg.ac.rs

EP 2014 (61) 3 (739-757) 